\title{
Impact of Organic and Inorganic Amendments on Yield and Growth of Wheat (Triticum aestivum L.)
}

\author{
Ajaypal Singh*, Mayur S. Darvhankar, Gurpreet Singh and Sonam \\ Department of Agronomy, Department of Vegetable, School of Agriculture, Lovely \\ Professional University, Jalandhar-Delhi G.T Road (NH-1), \\ Phagwara, Punjab, India \\ *Corresponding author
}

\section{A B S T R A C T}

\section{Keywords}

Organic manure, Inorganic fertilizer, Sewage sludge, Bone meal, Available nitrogen.

Article Info

Accepted: 06 July 2018 Available Online: 10 August 2018
Effect of organic and inorganic amendments on growth and yield of wheat were studied in alluvial soil in experiment farm of Lovely Professional University 2017-18. The experiment was laid out in Randomized complete block design with eight treatments were set and each replace three times. Totally eight treatments in which one control and one $75 \%$ RDF alone and five treatment consist combination of organic and inorganic amendments and one treatments is combination of organic manures. Growth parameters were recorded at 30,60 and 90 DAS and yield parameters are were recorded at the time of harvest. Plant height, leaf area per plant, number of grains per spike and grain yield of wheat was recorded. Result indicates that the application of $50 \% \mathrm{RDF}+0.4 \mathrm{t}$ sewage sludge $\mathrm{ha}^{-1}+0.25 \mathrm{t}$ bone meal ha ${ }^{-1}$ showed significant positive impact on plant height, leaf area per plant, number of grains per spike and grain yield of wheat.

\section{Introduction}

Wheat considered as the highest cultivated crop all around the world. It is good source of protein and provides a large fraction of the total food supply. Wheat is mainly grown in Punjab and some other states of India, but now cultivated worldwide. Total production of wheat all around world 2016-17 years was 724 million tons and rice was (494.4 million tons). The wheat considered grown under larger area than any other commercial food. Wheat has higher protein content than other major cereals crops, corn or rice. Wheat is a Rabi season crop of Central Zone and North Western Plain zone of India. Wheat grains are comparatively better source of protein consumed in India. Wheat fulfills the 10-20\% requirement of protein in India. The productivity of the wheat crop and the protein content could be increased by the use of different fertilizers. The imbalanced and heavy use of chemical fertilizer are two most important factors has led to think about the use of vermicompost, 
poultry manure, sewage sludge, bone meal, FYM, etc. in growing areas for sustainable production system. To achieve the potential of production and sustainability of crop, higher uses of vermicompost, poultry manure and their scientific management is very important. It must be stressed that the value of FYM, poultry manure, cattle slurry and vermicompost in soil improve the nutrient content, while helping in the improvement of water holding capacity and soil structure of soil. The seed produced under organic system has to be used for organic crop production. For the sake of continuing world energy crisis and spiraling price of chemical fertilizer, the use of organic manure as a renewable source of plant nutrients is assuming importance. In this endeavor proper blend of organic manure and inorganic fertilizer is important not only for increasing yield but also for sustaining soil health (Kumar et al., 2013). Vermicompost is rich in microbial populations and diversity, particularly fungi, bacteria, and actinomycetes (Edwards, 1988, Tomati, 1995) and also best result is obtained by the vermicompost at the growth of plants. The continuously use of chemical fertilizers effect on the human health and such as ground water, surface water polluted by the nitrate leaching (Pimentel, 1996).

Andhikari and Mishra (2002) showed that the mixed applications of vermicompost and urea can be reduced by $50 \%$ amount of urea in the field conditions. And, also the yield was $12 \%$ higher than by the use of vermicompost and urea.Wheat is important cereal crop and require a good supply of nutrients especially nitrogen for its growth (Mandal et al., 1992) and yield (Kirrilov and Pavlov, 1989) and also the best combination of organic and inorganic fertilizer for the growth and yield of wheat. Mainly application of organic and chemical fertilizers to improve the soil fertility, soil physical and chemical properties and increase yield (Ezekiel, 2010).
Organic manure increases the accumulation of the soil organic carbon (SOC), quality and quantity of various classes of organic compounds. Research on SOC following crops residue has been mainly focused on changes of bulk organic carbon. It is seen that the integrated use of concentrate organic materials and inorganic fertilizers has received considerable attention, in the past with a hope of meeting the farmer's economic need. It may also help to check the emerging deficiency of nutrients other than $\mathrm{N}, \mathrm{P}$ and $\mathrm{K}$ that brings economy and efficiency in fertilizers. The necessary nutrient management favorably affects the physical, chemical and biological environment of soil.

\section{Materials and Methods}

\section{Location of experimental site}

The experiment was conducted at the experimental Farm of the Department of Agriculture, Lovely Professional University, Jalandhar, Punjab (India) during 2017-18. The latitude $31^{\circ} 22^{\prime} 31.81^{\prime} \mathrm{N}$ and $75^{\circ} 23^{\prime} 03.02 \mathrm{E}$ longitude with altitude of $252 \mathrm{~m}$ above sea level, which falls under the central plain zone of Agra climate zone of Punjab. The soil was sandy loam with $\mathrm{pH}$ 7.6. The available $\mathrm{N}, \mathrm{P}$ and $\mathrm{K}$ content of soil were 246, 16.51 and 265 $\mathrm{kg} \mathrm{ha-}{ }^{1}$, respectively with organic carbon 0.38 $(\%)$ and Electrical conductivity $0.36\left(\mathrm{dSm}^{-}{ }^{1}\right)$.

\section{Experimental detail}

The experiment was laid out in Randomized complete block design with eight treatments were set and each replicate three times. Totally eight treatments in which one control, one treatment consist $75 \% \mathrm{RDF}$ and five treatments consist combination of inorganic fertilizers, organic manures and one treatment is the combination of organic manures. Table 1 shows the detail of treatments. 


\section{Agronomic practices}

Wheat variety HD 2967 was used in this research work. In addition to this, half dose of nitrogen and full dose of phosphorus and potassium were also applied as per treatment through urea, SSP and muriate of potash, respectively. The remaining half dose of nitrogen was applied at the time of earthing up. Wheat was sown by line sowing method at sowing depth 3-6 cm in the November, 2017.The $100 \%$ RDF contained $120 \mathrm{~kg} \mathrm{~N}, 60$ $\mathrm{kg}$ phosphorous, $40 \mathrm{~kg}$ Potassium per hectare and $75 \%$ RDF contained $90 \mathrm{~kg} \mathrm{~N}, 45 \mathrm{~kg}$ phosphorous and $30 \mathrm{~kg}$ potassium per hectare and $50 \%$ RDF contained $60 \mathrm{~kg} \mathrm{~N}, 30 \mathrm{~kg}$ phosphorous and $20 \mathrm{~kg}$ potassium per hectare and $25 \%$ RDF contained $30 \mathrm{~kg} \mathrm{~N}, 15 \mathrm{~kg}$ phosphorous and $10 \mathrm{~kg}$ potassium per hectare.

\section{Data collection}

The growth attributes (plant height and leaf area index) were taken at 90 DAS and yield attributes (Number of grains per spike and grain yield) were taken at harvesting.

\section{Statistical analysis}

Data were analyzed by Duncan's Multiple Range Tests (DMRT) for separation of means with a probability $p<0.05$. Difference between mean values was evaluated by Analysis of Variance (ANOVA) using the software SPSS 16.

\section{Results and Discussion}

\section{Growth attributes}

\section{Plant height}

Plant height ranged from 54.22 to $67.67 \mathrm{~cm}$ at 90 DAS. The highest value $(67.67 \mathrm{~cm})$ of plant height was recorded in $\mathrm{T}_{3}$ (50\%RDF+0.4t sewage sludge ha ${ }^{-1}+0.25 \mathrm{t}$ bone meal $\mathrm{ha}^{-1}$ ) followed by $\mathrm{T}_{1}(75 \% \mathrm{RDF})$ i.e. $66.30 \mathrm{~cm}$ while the lowest value $(54.22 \mathrm{~cm})$ was recorded in $\mathrm{T}_{0}$ (control). As compared to $\mathrm{T}_{0}, \mathrm{~T}_{3}$ showed $24.81 \%$ increase in plant height at 90 DAS. The reason of the highest plant height in this treatment is that the combination of RDF, sewage sludge and bone meal is having good amount of nitrogen and easily provided to plants which helps in good plant height. Same results were reported by Thakur et al. (2017).

\section{Leaf area per plant}

Leaf area per plant ranged from 196.62 to $227.34 \mathrm{~cm}^{2}$ at 90 DAS. The highest value $\left(227.34 \mathrm{~cm}^{2}\right)$ of leaf area per plant was recorded in $\mathrm{T}_{3}$ (50\%RDF+0.4t sewage sludge $\mathrm{ha}^{-1}+0.25 \mathrm{t}$ bone meal $\mathrm{ha}^{-1}$ ) followed by $\mathrm{T}_{1}$ (75\%RDF) i.e.222.86 $\mathrm{cm}^{2}$ while the lowest value $\left(196.62 \mathrm{~cm}^{2}\right)$ was recorded in $T_{0}$ (control). As compared to $\mathrm{T}_{0}, \mathrm{~T}_{3}$ showed $15.62 \%$ increase in leaf area per plant at 90 DAS. The RDF, sewage sludge and bone helps to increase these characters of wheat. Our results are in accordance with the result of Pietz et al., (1982) (Table 2).

\section{Yield attributes}

\section{Number of grains per spike}

Number of grains per spike ranged from 46.42 to 72.02 . The highest value (72.02) of number of grains per spike was recorded in $\mathrm{T}_{3}$ $\left(50 \% \mathrm{RDF}+0.4 \mathrm{t}\right.$ sewage sludge $\mathrm{ha}^{-1}+0.25 \mathrm{t}$ bone meal $\mathrm{ha}^{-1}$ ) followed by $\mathrm{T}_{1}(75 \% \mathrm{RDF})$ i.e. 70.32 while the lowest value (46.42) was recorded in $\mathrm{T}_{0}$ (control). As compared to $\mathrm{T}_{0}$, $\mathrm{T}_{3}$ showed $25.8 \%$ increase in number of grains per spike. Number of grains per spike is highest in $\mathrm{T}_{3}(50 \% \mathrm{RDF}+0.4 \mathrm{t}$ sewage sludge $\left.\mathrm{ha}^{-1}+0.25 \mathrm{t}_{\text {bone meal }} \mathrm{ha}^{-1}\right)$. This may be due to higher organic matter content in sewage sludge (Table 3 ). 
Table.1 Treatment detail

\begin{tabular}{|c|c|}
\hline $\mathrm{T}_{0}$ & Control \\
\hline $\mathrm{T}_{1}$ & $75 \% \mathrm{RDF}$ \\
\hline $\mathrm{T}_{2}$ & $50 \%$ RDF+6t FYM ha ${ }^{-1}+1 \mathrm{t}$ Poultry Manure ha ${ }^{-1}$ \\
\hline $\mathrm{T}_{3}$ & $50 \% \mathrm{RDF}+0.4 \mathrm{t}$ Sewage Sludge $\mathrm{ha}^{-1}+0.25 \mathrm{t}$ Bone Meal ha ${ }^{-1}$ \\
\hline $\mathrm{T}_{4}$ & $50 \%$ RDF+6t FYM ha ${ }^{-1}+1.5 t$ Vermicompostha $^{-1}$ \\
\hline $\mathrm{T}_{5}$ & $25 \%$ RDF+6t FYM ha ${ }^{-1}+1.5 \mathrm{t}$ Vermicompostha ${ }^{-1}+25 \%$ Bone meal \\
\hline $\mathrm{T}_{6}$ & $25 \%$ RDF+1.5t Vermicompostha ${ }^{-1}+0.4 \mathrm{t}$ Sewage Sludge $\mathrm{ha}^{-1}+1 \mathrm{t}$ Poultry Manure $\mathrm{ha}^{-1}$ \\
\hline $\mathrm{T}_{7}$ & $6 \mathrm{t} F Y M h^{-1}+1 \mathrm{t}$ Poultry Manure ha ${ }^{-1}+0.4 \mathrm{t}_{\text {Sewage Sludge }} \mathrm{ha}^{-1}+0.25 \mathrm{t}$ Bone Meal ha $\mathrm{h}^{-1}$ \\
\hline
\end{tabular}

$\mathrm{RDF}=$ recommended dose of NPK

Table.2 Effect of different organic and inorganic amendments on Plant height $(\mathrm{cm})$ and leaf area per plant $(\mathrm{cm} \neg 2)$

\begin{tabular}{|c|c|c|}
\hline Treatments & Plant height $(\mathrm{cm})$ at 90 DAS & Leaf area per plant $\left(\mathrm{cm}^{2}\right)$ at 90 DAS \\
\hline $\mathrm{T}_{0}$ & $54.22^{\mathrm{e}} \pm 1.36$ & $196.62^{\mathrm{e}} \pm 3.45$ \\
\hline $\mathrm{T}_{1}$ & $66.30^{\mathrm{ab}} \pm 1.67$ & $222.86^{\mathrm{ab}} \pm 3.91$ \\
\hline $\mathrm{T}_{2}$ & $63.84^{\mathrm{abc}} \pm 1.60$ & $220.22^{\mathrm{ab}} \pm 3.86$ \\
\hline $\mathrm{T}_{3}$ & $67.67^{\mathrm{a}} \pm 1.70$ & $227.34^{\mathrm{a}} \pm 3.98$ \\
\hline $\mathrm{T}_{4}$ & $62.59^{\mathrm{bc}} \pm 1.57$ & $215.95^{\mathrm{abc}} \pm 3.78$ \\
\hline $\mathrm{T}_{5}$ & $60.79^{\mathrm{cd}} \pm 1.53$ & $211.03^{\mathrm{bcd}} \pm 3.70$ \\
\hline $\mathrm{T}_{6}$ & $58.95^{\mathrm{cde}} \pm 1.48$ & $206.85^{\mathrm{cde}} \pm 3.62$ \\
\hline $\mathrm{T}_{7}$ & $56.76^{\mathrm{de}} \pm 1.43$ & $202.28^{\mathrm{de}} \pm 3.55$ \\
\hline
\end{tabular}

The mean followed by different letters are significantly different at $\mathrm{p}<0.05$, according to DMRT (Dum can's Multiple Range Test) for separation of means.

Note- T0-control, T1-75\% RDF, T2-50\% RDF+6t FYM ha ${ }^{-1}+1 \mathrm{t}$ poultry manure ha ${ }^{-1}$, T3-50\%RDF+0.4t sewage sludge $\mathrm{ha}^{-1}+0.25 \mathrm{t}$ bone meal ha ${ }^{-1}, \mathrm{~T} 4-50 \% \mathrm{RDF}+6 \mathrm{t}$ FYM ha-1+1.5t vermicompost $\mathrm{ha}^{-1}$, T5-25\%RDF+6t FYM $\mathrm{ha}^{-1}+1.5 \mathrm{t}$ vermicompost $\mathrm{ha}^{-1}+0.25 \mathrm{t}$ bone meal $\mathrm{ha}^{-1}$, T6-25\%RDF+1.5t vermicompost $\mathrm{ha}^{-1}+0.4 \mathrm{t}$ sewage sludge $\mathrm{ha}^{-1}+1 \mathrm{t}$ poultry manure $\mathrm{ha}^{-1}$, T7-6t FYM ha ${ }^{-1}+1 \mathrm{t}$ poultry manure $\mathrm{ha}^{-1}+0.4 \mathrm{t}_{\text {sewage sludge }} \mathrm{ha}^{-1}+0.25 \mathrm{t}$ bone meal ha $\mathrm{ha}^{-1}$

Table.3 Effect of different organic and inorganic amendments on Number of grains per spike and Grain yield

\begin{tabular}{|c|c|c|}
\hline Treatments & Number of grains per spike & Grain yield $\left(\mathrm{th}^{-1}\right)$ \\
\hline $\mathrm{T}_{0}$ & $46.42^{\mathrm{f}} \pm 0.68$ & $3.62^{\mathrm{f}} \pm 0.08$ \\
\hline $\mathrm{T}_{1}$ & $70.32^{\mathrm{ab}} \pm 1.03$ & $5.62^{\mathrm{b}} \pm 0.12$ \\
\hline $\mathrm{T}_{2}$ & $67.61^{\mathrm{b}} \pm .99$ & $5.33^{\mathrm{bc}} \pm 0.11$ \\
\hline $\mathrm{T}_{3}$ & $72.02^{\mathrm{a}} \pm 1.05$ & $6.0^{\mathrm{a}} \pm 0.12$ \\
\hline $\mathrm{T}_{4}$ & $64.06^{\mathrm{c}} \pm .94$ & $5.04^{\mathrm{c}} \pm 0.1$ \\
\hline $\mathrm{T}_{5}$ & $61.19^{\mathrm{d}} \pm .89$ & $4.70^{\mathrm{d}} \pm 0.1$ \\
\hline $\mathrm{T}_{6}$ & $57.16^{\mathrm{e}} \pm .83$ & $4.54^{\mathrm{d}} \pm 0.09$ \\
\hline $\mathrm{T}_{7}$ & $55.23^{\mathrm{e}} \pm .80$ & $4.13^{\mathrm{e}} \pm 0.08$ \\
\hline
\end{tabular}

The mean followed by different letters are significantly different at $\mathrm{p}<0.05$, according to DMRT (Dum can's Multiple Range Test) for separation of means.

Note- T0-control, T1-75\%RDF, T2-50\%RDF+6t FYM ha ${ }^{-1}+1 \mathrm{t}$ poultry manure ha ${ }^{-1}$, T3-50\%RDF+0.4t sewage sludge ha ${ }^{-1}+0.25 \mathrm{t}$ bone meal ha-1, T4-50\%RDF+6t FYM ha ${ }^{-1}+1.5 \mathrm{t}$ vermicompost ha ${ }^{-1}, \mathrm{~T} 5-25 \% \mathrm{RDF}+6 \mathrm{t}$ FYM ha ${ }^{-1}$ $+1.5 \mathrm{t}$ vermicompost $\mathrm{ha}^{-1}+0.25 \mathrm{t}$ bone meal ha ${ }^{-1}, \mathrm{~T} 6-25 \% \mathrm{RDF}+1.5 \mathrm{t}$ vermicompost ha ${ }^{-1}+0.4 \mathrm{t}$ sewage sludge ha ${ }^{-1}+1 \mathrm{t}$ poultry manure ha ${ }^{-1}$, T7-6t FYM ha ${ }^{-1}+1 \mathrm{t}$ poultry manure ha- $1+0.4 \mathrm{t}$ sewage sludge $\mathrm{ha}^{-1}+0.25 \mathrm{t}$ bone meal ha $\mathrm{h}^{-1}$ 
Sewage sludge can improve physical, chemical and biological properties of soil. It helps to reduce soil erosion and improves the soil quality as a plant growth medium. The fertilizer effect enables a reduction in cost for nitrogen and phosphorus mineral fertilizers and may improve crop yield on sludge treated fields.

Hence, number of grains per spike was highest. The findings of present investigation are nearly similar with the findings of Abedi et al., (2010).

\section{Grain yield}

Grain yield $\left(\mathrm{t} \mathrm{ha}^{-1}\right)$ varied from 3.62 to 6.0 $\mathrm{t} \mathrm{ha}^{-1}$. The highest value $\left(6.0 \mathrm{t} \mathrm{ha}^{-1}\right)$ of Grain yield $\left(\mathrm{t} \mathrm{ha}^{-1}\right)$ was recorded in $\mathrm{T}_{3}$ (50\%RDF+0.4t sewage sludge $\mathrm{ha}^{-1}+0.25 \mathrm{t}$ bone meal ha ${ }^{-1}$ ) followed by $\mathrm{T}_{1}(75 \% \mathrm{RDF})$ i.e. $5.62 \mathrm{t} \mathrm{ha}^{-1}$. The lowest value $(3.62 \mathrm{t}$ $\mathrm{ha}^{-1}$ ) was recorded in T0 (control). As compared to $\mathrm{T}_{0}, \mathrm{~T}_{3}$ showed $12.86 \%$ increase in Grain yield ( $\left.\mathrm{t} \mathrm{ha}^{-1}\right)$.

Grain yield $\left(\mathrm{t} \mathrm{ha}^{-1}\right)$ value is high in $\mathrm{T}_{3}$ which contain 50\% RDF, 4t sewage sludge $\mathrm{ha}^{-1}$ and $0.25 \mathrm{t}$ bone meal ha ${ }^{-1}$. We know that the RDF when we apply to soil, it give result to plant very quickly. Because the RDF dissolve in soil very fast and RDF give good result during early period of crop and remaining organic manure that taken some time to decompose in soil and that's why the sewage sludge and bone meal decompose after some time and crop taken benefit after flowering and good fruit set and give good grain yield. And this result is nearly similar with the result of Khan et al., (2007).

Based on the present study it was concluded that the combination of RDF, sewage sludge and bone meal helps to improve the growth and yield characters of wheat which plays an important role in the sustainable agriculture.

\section{References}

Abedi, T., Alemzadeh, A. and Kazemeini, S.A., 2010. Effect of organic and inorganic fertilizers on grain yield and protein banding pattern of wheat. Australian Journal of Crop Science, 4(6), p.384.

Adhikari, N.P. and Mishra, B.N., 2002. Effect of integrated sources of nitrogen on yield of aromatic rice and their residual effect on succeeding. In Extended Summaries: 2nd International Agronomy Congress (Vol. 1, pp. 26-30).

Edwards, C.A. and Burrows, I., 1988. Potential of earthworm composts as plant growth media. Earthworms in waste and environmental management/edited by Clive A. Edwards and Edward F. Neuhauser.

Ezekiel, Thomas, and Nyangani (2010). Effect of combined application of organic manure and chemical fertilizer on soil properties and crop yields. Nig. $J$. of sci., Tech. and Environ Edu. (NIJOSTEE), 3 10331-98732.

Khan, M.A., Kazi, T.G., Ansari, R., Mujtaba, S.M., Khanzada, B., Khan, M.A., Shirazi, M.U. and Mumtaz, S., 2007. Effects of un-treated sewage sludge on wheat yield, metal uptake by grain and accumulation in the soil. Pakistan Journal of Botany, 39(7), pp.25112517.

Kirrilov, Y.A.I. and Pavlov, V.D., 1989. Effect of fertilizer on yield and protein contents in wheat grain. Agrochimiya, 1, pp.49-51.

Kumar, M., Bauddh, K., Kumar, S., Saingar, M., Saingar. P.A. and Singh, R.P. (2013). Increase in growth, productivity and nutritional status of wheat (Triticum aestivum L. cv. WH711) and enrichment in soil fertility applied with organic matrix entrapped 
urea. J. Environ. Bio. 34: 1-9

Mandal, N.N., Chaudhry, P.P. and Sinha, D., 1992. Nitrogen, phosphorus and potash uptake of wheat (var. Sonalika). Env. and Eco, 10, p.297.

Pietz, R.I., Peterson, J.R., Hinesly, T.D., Ziegler, E.L., Redborg, K.E. and LueHing, C., 1982. Sewage Sludge Application to Calcareous Strip-Mine Soil: I. Effect on Corn Yields and N, $\mathrm{P}, \mathrm{K}, \mathrm{Ca}$, and $\mathrm{Mg}$ Compositions 1. Journal of Environmental Quality, 11(4), pp.685-689.

Pimentel, D., 1996. Green revolution agriculture and chemical hazards.
Science of the total environment, 188, pp.S86-S98.

Thakur, R., Khandkar, U.R., Nath, D., Patidar, R.K. and Patidar, N.K., 2017. Documentation on Enhancing Nutrient Uptake and Yield of Rice with Application of Sewage Sludge and Different Fertility Levels on Sodic Vertisols. Int. J. Curr. Microbiol. App. Sci, 6(10), pp.2986-2998.

Tomati, U. and Galli, E., 1995. Earthworms, soil fertility and plant productivity. Acta Zoologica Fennica, 196, pp.1114.

\section{How to cite this article:}

Ajaypal Singh, Mayur S. Darvhankar, Gurpreet Singh and Sonam. 2018. Impact of Organic and Inorganic Amendments on Yield and Growth of Wheat (Triticum aestivum L.). Int.J.Curr.Microbiol.App.Sci. 7(08): 789-794. doi: https://doi.org/10.20546/ijcmas.2018.708.088 